\title{
Ecological Spatial Regulation in China: Understanding Conservation from the Strategic Relational Approach
}

\author{
Dan Lin \\ Department of Landscape Architecture, Shenzhen Tourism College of Jinan University, China
}

Copyright $\subset 2016$ by authors, all rights reserved. Authors agree that this article remains permanently open access under the terms of the Creative Commons Attribution License 4.0 International License

\begin{abstract}
Recent theories and practices have demonstrated the evolving approaches to ecological conservation reflecting not merely a transition in ecological technology, but more a question of social power, in particular the power of the state and its capabilities in balancing other forces and demands from society. A framework that is based on the strategic-relational approaches is able to capture the multidimensionality of the relations between nature and society increasingly mediated by the state. The evolving approaches to ecological designation in China provide a paradigmatic example of how the scope of ecological conservation is being shaped by particular political, economic and social context in China. The empirical results based on qualitative research methods show that, the designation of ecological conservation areas in China is part of broader strategies to reorder state space serving socio-political as well as ecological ends. What matters is the political structuration of choices about ecological conservation, i.e. the 'strategic and selectivity' of the state.
\end{abstract}

Keywords Ecological Conservation Policy, China, Strategic Selectivity

\section{Introduction}

The term 'ecological conservation' refers to the set of interventions that seek to preserve, conserve or restore species, habitats and ecosystems of nature and ecology, in other words, 'the ideologies and practices of preservation, protection and enhancement of nature' [1]. As Adams (1997) has pointed out, this form of intervention involves 'a complex range of social practices relating to the human use of non-human nature', for instance, resource management, nature protection, and ecological restoration [2]. The state designation of ecological conservation areas has been one of the main strategies involved in practices of ecological conservation [3]. With the consolidation of the state, the designation of ecological conservation areas have demonstrated a shift away from the initial protection of areas as wilderness areas $[1,4,5]$, through to habitat management to protect particular species $[1,6-8]$; and latterly an increasing emphasis on ecosystem management $[2,9,10]$. It is also worth noting that the state may work at different spatial levels, affecting designations of land for ecological conservation (esp. in Federalized or devolved or decentralized states). The evolving approaches to ecological conservation reflect, as discussed in strands of literature in ecology, political ecology and human geography [2, 11-13], not merely a transition in ecological technology, but more a question of social power. At the centre has been the power of the state and its capabilities in balancing other forces and demands from the society [14]. Critical assessment and appraisal are thus required to understand the processes and impacts of the government's attempts to protect and preserve ecological resources by designating protected conservation areas.

An investigation of the evolving approaches to the designation of ecological conservation areas in China serves as a case study to contribute to our understanding of the political economy of the state to protect and preserve ecological areas by designating ecological conservation areas in one highly contested institutional context. China is biologically among the richest countries in the world. In her rush to development, China has stepped aside from long standing traditions and values of a distinctively 'Chinese' approach to the 'Tian Ren $\mathrm{He} \mathrm{Yi}$ ' philosophy of society-nature relations. What this has led to is that the country has not had a rigorous system of protection and in some respects lagged behind international ecological conservation practice. During the past 35 years, however, ecological conservation policy in China has developed rapidly, with its approaches shifting from single site protection to ecological system management. Although some academics insist that it might be inappropriate to apply western theory into analysis on Chinese cases, I argue that such understanding is based on presumptions about the international isolation of China. In fact, the country's commitment to adopting more international norms and rules since its entrance into the WTO has brought along changes in 
various aspects of the society, which poses significant challenge to the previous assumption. Recent years have indeed witnessed increased research on environmental protection and its policy evolution to confront with problems in land use, air quality, urban air pollution, toxic waste, dam construction, and riverine conservation etc. in China e.g. [15-19]. Ecological spatial conservation is among the most widely implemented ecological conservation practices as being reflected in the burgeoning of territories of ecological reserve across the country over the past 35 years. My present concern is thus focusing specifically on the designation of ecological conservation, with understanding how the scope of ecological spatial regulation is being shaped by particular political, economic and social context in China. An interpretation of China's case could further help us to answer the question of 'how the designation of ecological conservation areas is formed in specific economic, politics and culture' background. Without such an understanding, we are left with an inadequate analysis that creates the condition for ill-informed policy decisions by decision makers at both the international and national scale.

The case study based on qualitative research methods is adopted to reflect on political and social dynamics in relation to the evolving process of the designation of ecological conservation areas in China. Multiple sources of evidence were collected and triangulated, including official and non-official documents, non-participant observation, interviews. Systematic data analysis shows that evolving approaches to ecological spatial regulation in China reflect not merely a transition in ecological techniques, but more a question of social power. In addition to this, ecological conservation policy is developing rapidly, not least as international regulations are being continuously integrated with economic policy [20-22]. This could be seen as part of a new stage of economy-environment and society-ecology relations following three and a half decades where economic development has largely dominated Chinese policy.

The main contribution of this study is an attempt to link the emerging practices of ecological designation with the framework developed by Bob Jessop (2008), the so-called, 'strategic relational approach'[23]. Within this framework, the designation of ecological reserves has been seen as being comprised of a set of interventions (including legislation and other forms of political and social practices) dedicated to the protection of ecological spaces, the significance of which is relative to their ecological, economic, and social values. The activity of the designation of ecological conservation provides a focus for negotiation [11], in which a mix of state and non-state actors, situated at different geographical scales of decision-making, are usually involved $[11,24,25]$. Their competing claims over the use of ecological reserves shape a set of forces, pressures, demands, and opportunities towards national and sub-national governments.

The paper is organized as follows: it starts by outlining a conceptual framework for examining evolving approaches/policies to ecological conservation as a state project. This framework has been based on the concept of 'strategic selectivity', which intends to rethink and re-establish human-nature relations considering the interaction between nature and human society. Power relations that shape some particular conservation strategies are to be examined. This is followed by a detailed explanation of research methodology. The next section deals with the experience of the designation of protected areas in China. The fourth section provides an account of interest groups that have been variously involved in the decision-making process, explaining how their 'strategic calculations' around the designation of the ecological conservation areas has formed a set of forces towards the state in policymaking. The paper concludes by reflecting on the implications of policies and their future development.

\section{Theoretical Framework}

Ecological resources have a variety of economic, social and ecological values in supporting the human use of non-human nature, notably: the provision of material goods for direct use, for example, products that are consumed directly (e.g. fresh water, food, fibre and fuel, and air) [26-28], and products that are used commercially (e.g. timber, fish, bamboo) $[26,29,30]$; nonmaterial benefits for indirect use, such as cultural, spiritual and recreational services [27, 28, 31, 32]; and underpinning functions (e.g., carbon storage, sequestration wetland's natural function, climate regulation, and nutrient cycling [27, 28, 33, 34]. There are also optional values $[35,36]$ of ecological resources, which stress the 'value for preserving the option to use ... services in the future either by the individual (option value) or by others or heirs (bequest value)' [33].

A range of social practices thus seek to preserve, conserve, or restore these ecological resources are involved in ecological conservation. Dominant conservation practices have changed over time in response to different challenges, and changes in value positions and scientific understanding. It is possible to identify a number of key paradigms of state ecological conservation policy: (1) wildlife preservation; (2) habitat management to protect particular species underpinned by equilibrium ecology; and (3) an increasing emphasis on ecosystem management and ecological governance, as reflected in ecological corridors and green infrastructure projects, which attempt to connect landscape-scale habitats and green space. The designation of these ecological spaces often involves the setting of spatial boundaries $[2,6,7,37]$ to address spatial claims of different demands on ecology, or social, or economic development, which therefore raises several questions about the decision-making process, notably: where to delineate boundaries, how to define the conservation unit, and how to create a suitable conservation and management strategy [11].

In order to understand the above-mentioned state designation of ecological conservation areas, two strands of 
theory could be referred to. The first is the concept of 'ecological modernization'. Ecological modernization is 'a concept dealing with the institutions of modern technology, (market) economy and state intervention' [38]. This line of theory notifies the increasing importance of economic and market dynamics in ecological reform and the increased adoption of environmental policy objectives by private business, such as practices of self-regulation, or waste reduction. Within the framework of 'ecological modernization', the environmentally regulatory procedures of the state are something that needs to be adopted carefully in facilitating or contextually 'steering' the process of modernization, whereas modern science and technology should play as major institutions in ecologizing the economy [39-41]. However, the role of the state in response to ecological challenges in contemporary industrial societies may be more complex than it has been assumed in the concept of ecological modernization. As argued by Harvey (1996), the concept of ecological modernization ignores the fact that the ecological modernization could be a discourse that may serve as a 'discursive representation of dominant forms of economic power' [42].

An alternative view elaborates on the relations between the nature of power and the strategic selectivity of the state in relation to certain projects as well as policies. This view attempts to understand the designation of ecological sensitive areas as state interventions, which is part of an ongoing restructuring of the state in relation to environmental regulation [25]. The key to this understanding is the concept of 'strategic selectivity' [43]. Following on from Giddens' structuration theory, Jessop as well as Hay [44, 45] conceptualize a more dynamic model of the structure/agency relationship through the concept of strategic-relational approach (SRA). The concept of SRA examines the dialectical relationship between structure and agency [14]. In the SRA, structures are treated 'as strategically-selective in their form, content, and operation' [46]. Differing from Gidden's tendency to view structures as rules and resources, the SRA highlights the 'distinctive spatio-temporal selectivities of structures and the differential spatio-temporal horizons' [46], through which 'specific structures and structural configurations' 'selectively reinforce specific forms of action, tactics, or strategies and to discourage others' [46]. In other words, within in this context, some strategies seem to be privileged over others. Agency/action, on the other hand, is defined as 'structurally constrained, more or less context-sensitive, and structuring' [46]. The nature of structural forces is likely to vary over different spatial scales and timescales (a short-term constraint may emerge as a long-term opportunity) or spatial scales. Action capacities of individuals or groups are explicitly explained through the concept of 'structurally-oriented strategic calculation' [46, 47]. This concept highlights the capability of agents to reflect on the strategic selectivities inscribed within structures, and their own identities as well as interests, in this sense, they are able to adopt particular strategies and tactics in order to continually remold the social structures and their emergent property [46]. The extent to which the reflexive reorganization of structural configurations may reach depends on structurally inscribed strategic selectivity. Meanwhile, the ability of actors to alleviate the structural constraints and the recursive selection of strategies and tactics is subject to the learning capacity of individuals or groups and experiences they obtain during the interaction process [46]. Consequently, it is possible to view the recursive interaction between the strategic selectivities of structures and the reflexive behavior of agents as a complex interplay of intentions and constraints, which produces a structurally coherent, apparently self-reproducing social configuration [46,47]. This coherence is multiply tangential [46], which creates strategic opportunities for agents; in particular the powerful yet constrains simultaneously the powerless and the subordinated [45]. This nevertheless suggests the feature of path-dependency, which implies that 'a structure's prior development shapes current and future trajectories and possibilities for structural transformation and innovation' [46]. However, such transformation is shaped by both 'the gradual accumulation of the unintended consequences of social action' and social forces, during which new trajectories become possible [46].

Informed by the SRA, it could be argued that as an institutional ensemble of power centre which exist in relation to the balance of political forces, the state is not a neutral organization for the provision of the common good, but a dynamic institution that offers unequal opportunities to different social groups, so that they could achieve their specific political purposes [43]. Given competing human demands for ecological resources [11], the designation of ecological conservation areas may have affected the 'rights' and 'interests' of existing users of certain spaces [11]. Beyond this, the scaling of ecological conservation areas as a process provides a focus for negotiation or conflict among a variety of interest groups, covering a gamut of geographical areas (for example, between local institutions and the varied makers of conservation territories that typically include national agencies and international organizations) [2,11,48]. Therefore, a variety of agents who continually examine the options open to them in pursuing their various interests has been involved in the process of designation, including: governmental decision-makers, scientist and those who practically experience the environment related events and problems. In this sense, decisions made to choose certain strategies or policies of the designation of ecological reserves could thus be argued as reflecting the 'strategic selectivity of the state' since 'governments seek to balance environmental and ecological goals with other forces, pressures and demands within the wider society' [49].

\section{Research Methods}

Given that this research aims to explore why and how certain social relationships are related to the construction of 
the protected areas rather than the built environment in itself, a qualitative methodology is employed. A qualitative methodology is useful to 'to broaden and/or deepen our understanding of how things came to be the way they are in our social world' [50], by describing 'from the inside out' based on the viewpoint of people who play a part [51]. The study draws upon a continued tracking of China's conservation practices from 2008, covering two main phases of data collection. The first phase went through from 2008-2010 when the author was conducting her doctorate field research at both national and local scale in China, mainly in the city of Beijing and Shenzhen. After the completion of the doctorate research, the author continued with relevant research by supports from China National Social Science Foundation, which allows her to expand filed investigation into covering another three cities located in South, Central, North, and West of China, providing a panoramic view of conservation practices across China. Multiple sources of evidence were collected and triangulated [52] to construct validity and reliability of the study during these two phases. They are:

Official and non-official documents: These include Yearbooks, Annual Statistic Reports and relevant publications, Socioeconomic development plans and policies, government policy documents and archival records including key laws and actions on ecological conservation at both national and local level, Main Research Reports, and non-official documents (e.g. newspapers, memoir etc.) that have noted the evolving process of ecological conservation in the country, literature on the studies of contemporary China written and published by scholars. However, there are potential problems inherent in the collection and interpretation of secondary information [53]. In the first place, the accessibility of official data/documents in China has proved to be a problem [54]. This may affect the representation of the collected data. In order to avoid this shortcoming, the author had tried many channels to get access to documents during the research process. For instance, data was obtained during the fieldwork from the National Library, where historical data were collected systematically, and which are open to the public. Parts of the data were obtained from local Archives by application.

Interviews and observation: Documentary analysis has been triangulated with data collected from interviews and observation [55]. In total, fifty semi-structured interviews were conducted with interviewees at both national and local scales (i.e. the city of Shenzhen, Guiyang, Handan, Wuhan), covering governmental officials severing for State Environmental Protection Administration, State Development and Reform Commission, State Construction Ministry, and State Land and Resource Administration Ministry; local residents, in particular those being affected by conservation practices; community activists; ENGOs at national and local scale; and business operators. Three types of interview were employed: open-ended interviews with key actors being involved in the policy making process in order to narrow down research questions and themes/issues; semi-structured interviews informed by both theoretical framework and fieldwork; and focus Groups to explore consistent and shared views [56]. These interviews were audio taped, or noted when no audio-tape was required by the participants. All the interviews were transcribed with key quotations being translated into English at the stage of writing up. This information was supplemented by thorough readings of key policy documents, other ancillary texts, newspaper accounts, and websites. Non-participatory observations in the above-mentioned field study cities were done in alignment with field note, including photos taking, live commentaries recording, and quick sketches drawing.

The whole research process is a continuous and interactive process reflecting the model of 'data collection, followed by analysis and memo writing, leading to questions, that lead to more data collection, and so on' [57]. Data analysis begins during the process of data collection and consistently shapes the ongoing data collection [58]. Three ongoing and cycle steps are involved and interwoven in data analysis. Data was firstly coded and organized by preliminary analytical framework. Of those data that fell beyond the framework, they were saved as descriptive free codes for further analysis. Following the initial data organization and coding process, codes were categorized and sub-categorized through systematic and constant comparison [57] in which each item was checked or compared with the rest of the data on the one hand, and with research questions on the other hand. Informed by the analytical and theoretical ideas developed during the research, categories were further refined and grouped together by revisiting the research questions [57] in order to model relations among themes. Data analysis, however, 'is not a structured, static, or rigid process. Rather, it is a free-flowing and creative one in which analysts move quickly back and forth between types of coding, using analytic techniques and procedures freely and in response to the analytic task before analysts' [57]. In the following section, the argument will move towards discussion on the evolving approaches to ecological conservation in a unique ecological, culture and political context.

\section{Evolving Approaches to Ecological Spatial Regulation Policy in China}

China has a long history in ecological conservation dating back to the Qin Dynasty, which had then experienced turmoil up until the pre-reform era. 'The country's Reform and Openness in 1978 brought about not only economic integration into the international market but also multi-dimensional acceptance of international norms and regulations. Ecological conservation is not an exception in this regard. In February 1978, the Chinese Academy of Science (CAS) established the 'Man and the Biosphere' National Committee, and in 1979 the first comprehensive environmental law, the 'Environmental Protection Law' was promulgated [59].After 1979, standards were established requiring the protection of ecologically significant species 
[60], followed by an increase in the number of protected areas and ecological conservation areas national wide. By the end of the 1970s, a conservation programme was put forward proposing basic principles for establishing a network of ecological conservation areas. Over 100 reserves were set up in 1981 alone, such pace of expansion remained over the next decade and a half [61]. Up until 1991, 708 protected areas had been established [20].

While significant measures have been taken to improve the range (and scope) of protected areas an unintended consequence is that protected area provision does not necessarily correlate to an equal increase in the quality of the protection and conservation of ecological spaces. It could be seen that the selection of areas seemed to be problematic. For instance, many conservation areas contain no ecologically significant species or resources [62]. Conversely, a number of important habitat types were found to be unrepresented or underrepresented. A case in point is that some areas of ecological diversity and significance and containing endangered and threatened species were managed by the military, and were excluded from the reserve system [63]. Meanwhile, some reserves were too small to become viable ecological systems in the long run, especially those being designated by local governments. In terms of management, most of the nature reserves were little more than 'paper parks', especially those reserves in remote areas in China, with human exploitation of the areas continuing unchecked [61]. In addition, the lack of any form of biodiversity inventory with which to establish sound strategies for the management of forest blocks, new plantations, marine areas and rural habitats has further compromised the implementation of the policy.

Overall, the ecological conservation strategy which had led to some areas being better protected than others during the period 1949-1990 tended to be attributed to the 'strategically selective context'. The significant feature of this selectivity has been the priority being given to the economic use value of ecological areas in policymaking at national scale. The transition from a planned economy towards the socialist market economy brought with it growing concern for rapid industrial growth and urban expansion at different levels of decision-making, and this soon became the most severe challenge to nature conservation since the enactment of ecological conservation policies, including the deregulation of some aspects of natural resources such as forests to make them available for capital accumulation [61]. Within this sociopolitical context, ecological conservation has been regarded as a burden for local government, where growth is dependent on a resourced-based economy. In these areas, local governments are largely locked into the entrepreneurial growth paradigm in terms of attracting inward investment, increasing local financial revenues and promoting competitiveness [64] through the so-called 'low-road' development strategy [65]. In the context of insufficient state subsidies, these local governments may lose their incentives to promote nature conservation and may not actively pursue the conservation and management of those protected areas. Moreover, this has led to increased revenue-raising activities within reserves, including tourism development and the use of natural resources in some cases [61]. There is also evidence of the deregulation of certain ecological space by some local governments for accumulation in the form, for instance, of transforming agricultural land into industrial and urban use [66]. Most significantly, due to the lack of the participation of civil society, most ecological reserves were in practice 'paper parks', which continued to suffer ongoing human exploitation.

In 1991, the Chinese central government enacted statutory procedures to encourage the establishment of protected areas at county, provincial and national levels [67], implying an attempt by the state to strengthen government functions and thus to improve the effectiveness of the management of protected areas. In principle, the designation and management of these (new) protected areas is structured by three main strategies: the identification of the aim of ecological conservation through a national planning framework that establishes a "quota and list" system; the formulation of principles and criteria for the designation and management of conservation reserves, and the establishment of statutory procedures for the designation of conservation areas. The national conservation planning framework identifies the pivotal role of government at different scales and their cooperation in conservation, in respect of the maintenance of biodiversity and the restoration of certain rare, threatened, or typical natural habitats and species to favorable conservation status[67]. In order to achieve this aim, a quota and list system was compiled to specify a quota in terms of numbers and areas of new conservation areas to be attained by different stages of national economic and social development at both national and regional scale. For instance, in the natural reserve region of hilly Southeast China, where scientific evidence indicates that species are becoming rarer as a result of development pressures, more than $5 \%$ of the total area is expected to be designated as protected area [67]. In total, nine (national) bio-geographical regions are defined in the national conservation planning framework, covering regions with different resource endowments (though social and economic development features are partially concerned) [67].

Principles for the designation and management of conservation areas are underpinned by a set of norms and standards from international to sub-national scales, such as the World Conservation Union (IUCN) categories I-IV, national standard for conservation areas, national lists of endangered wildlife and plants (NLEWP), and national or provincial guidelines for PA establishment. NLEWP is formulated by relevant departments in the Forest Bureau, Agriculture Bureau, National Environmental Protection Agency of China (NEPA), and Construction Bureau [68]. Primarily underpinning these principles are ecological criteria specified by island biogeography theory and landscape ecology, which focus on indicators such as rarity, biological importance, frequency, and distribution 
underlined by relevant ecological and biological principles. All these strategies listed above were strengthened by statutory procedures enacted by the China central government. A three-stage procedure was incorporated in the Regulation of Nature Reserves promulgated in 1994, which includes: 1) site identification and selection; 2) information collection and document preparation; and, 3) assessment and ratification, covering county, provincial and national levels. This procedure provides an institutional channel for the participation of scientists, in particular 'established academics' or heads of relevant governmental agencies or 'senior technical experts', in the decision-making process for the designation, planning and the ratification of conservation areas in order to make authoritative suggestions for the establishment of conservation areas [69], and the assessment and ratification of an application. These experts are organized through the National Nature Reserve Assessment Committee, whose membership should be approved by the State Ministry of Environmental Protection [69]. The role of sub-national levels of government is also stressed by this procedure. For instance, a provincial-level government (including province, municipality or autonomous region) is required to draw up its own lists of proposed sites for conservation on the basis of the lists compiled by its functional units or lower-levels of government, and then submit the final list to relevant central governmental agencies (e.g. NEPA and Ministry of Housing and Urban-Rural Development of the People's Republic of China) for approval [70].

Within the strengthened ecological regulation regime, according to the NEPA (NEPA 2010) the number of nature reserves increased to 2,588 by 2005 , with their total area of over $149 \mathrm{mha}$ amounting to $14.9 \%$ of China's territory notably exceeding the world average of 10 percent. This trend appears to continue. After the implementation of the Wildlife Conservation and Nature Reserve Construction Project in December 2001, the State Forestry Administration (SFA) intends to establish another 2,500 nature reserves by 2050 , which may cover 172.8 million ha occupying a further 18 percent of China's total land area (NEPA 2010). The aesthetic value of nature is increasingly emphasized in the guidelines of designation for ecological conservation. For instance, several reserves (e.g. Jigong Shan Reserve, Daming Shan Reserve, Dinghu Shan Reserve, Wuling Shan Reserve) were established to preserve areas of special significance, including watershed forests, seed forests, geological sections, glacial remains, karst landscapes, hot springs, fossils and historical remains, and geological relics with high heritage and landscape values.

The concept of 'ecological function conservation areas' was introduced in 2007 [71]. This aims to promote harmony between man and nature, which is expected to be achieved by the zoning of ecological function areas, which are defined as: 'Areas that are selectively designated in key ecological functional areas that have a significant role in water conservation, soil and water conservation, flood storage, wind fixing, and the maintenance of biological diversity.
Within these areas, development and construction are restricted. Ecological function areas are keys to the protection of regional ecological function, the prevention and mitigation natural disasters, the coordination of regional ecological protection and socioeconomic development, and the protection of national and local ecological security. Ecological function areas should be jointly managed by the central and local governments' [72]. In these ecological function areas, inappropriate resource development activities would be controlled, and top priority would be given to conservation supported by techniques of natural rehabilitation. The concept of

conservation-with-development has also been stressed [71].

\section{The Strategic Selectivity of the State Ecological Conservation Policy}

The transition of ecological conservation in China from weak to strong ecological regulation as introduced above could be regarded as being shaped by the altered 'strategically selective context'. The state governments at various levels remain the power center in decision-making in relation to ecological conservation. Different ministries or administrations at various levels (both central state and local governments) are working together to jointly manage conservation reserves according to their conservation status (national, provincial, municipal, etc.) which classified by the significance of their ecological, economic and social values. However, the differences existed in the 'strategic calculations' around the designation of the ecological conservation areas by various interest groups form a set of forces, pressures, demands, and opportunities towards national and sub-national governments.

At the outset, the State's intervention into ecological conservation has been pressed by international norms and rules, such as increasing pressure from ecological conservation legislation, conservation agendas or targets set by higher levels of institutional or organizational involvement [73]. In line with such international integration is the transition of national development ideology from the one in which priority was given to rapid economic growth to the one that stresses the ecological value of nature in 'sustainable development', and the 'harmonious development' ideology, within which various levels of government have demands in investing in conservation infrastructures [74,75], including preserving, conserving or restoring ecological landscapes or places. This includes the need to invest in ecological infrastructure in order to maintain and create the necessary conditions for growth [76] and to win inter-place competitions in terms of attracting investment or workers in the future. In the meantime, neo-liberalist approaches to ecological conservation have become new opportunities for the city and region to engage in ecological conservation markets to offset higher financial returns on conservation input $[74,77,78]$. The international and national ideologies opened up debates in various ways of 
valuing and consuming nature. In this context, various pressures for ecological conservation towards the state arise from the society $[25,77,78]$, involving actors such as ENGOs (environmental nongovernmental organisations), environmental social movements, relevant professions and scientists [79]. Some capitalist companies whose commercial interests are based around the conservation of ecological reserves are also part of or provide support to conservation pressure groups. The state is still facing challenges from pressures against ecological conservation from growth coalitions, which eventually compromises the strengths of these ecological policies. These groups involve governmental or non-governmental groups whose interests rely mainly on developmental activities [75], which exert an influence on ecological spaces.

Through balancing these demands and pressures across a state's space, the establishment of ecological conservation areas in China has shifted from simply protecting some endemic, rare and valuable species and their habitats or breeding areas, through to a re-strengthened ecological regulation regime, and an emphasis of ecological function conservation areas underpinned by the concept of ecosystem management within a new framework to stress ecological governance.

\subsection{Pressures for Ecological Conservation from International and National Norms and Rules}

Ecological conservation in China witnessed what Falkner [80] has described as increased exposure to the global system of environmental governance. In February 1978, the Chinese Academy of Science (CAS) established the 'Man and the Biosphere' National Committee, and in 1979 the first comprehensive environmental law, the 'Environmental Protection Law' was promulgated [81].Since 1990, the country has committed to adopting more international norms and rules, including UNESCO's Man and Biosphere Program (MAB), the World Heritage Convention (WHC), the International Important Wetlands List, the RAMSAR Convention, Convention on International Trade in Endangered Species of Wild Fauna and Flora (CITES), and the Migratory Bird Conventions. In the early 1990s, the country ratified both the Convention on Biodiversity (CBD) and Wetland Convention. China is also a party to the (now supereceded) Kyoto Protocol on climate change and the Convention on Biological Diversity (CBD) [82]. Since the Rio Conference, international cooperation and exchange to and within China have become more in-depth and extensive [83]. China has begun to participate in international initiatives such as the Geo-parks Network assisted by UNESCO, which provides new opportunities for exploring development-conservation relations [84]. For the state, these international norms constitute important normative and regulatory context for the adoption of environmental laws and regulations of the country.

\subsection{Demands for Ecological Conservation from Local Development Strategies}

Even though economic growth and development are still addressed by the central state, priority in national policy formation has been given to employment, social security, poverty reduction, education, health care, environmental protection, and safety [85]. For instance, China's Eleventh Five-Year Plan (2005) was a prelude to the exploration of creating a 'harmonious socialist society' by 'scientific development' and 'putting people first', which demonstrated a shift in national policy in dealing with economy-environment relations [85]. The Eleventh Five-Year Plan (2005) proposed that development would include both economic development, which should be based on the carrying capacity of the natural environment, and social development, which should address the issues of employment and income inequality, regional inequality, rural-urban inequality, and social safety [86]. Additionally, the Eleventh Five-Year Plan has also been regarded as revolutionary in its shifting of the role of the state away from detailed planning and towards the taking of greater responsibility in strategically compiling macro, broad directions while leaving more room for both market mechanisms and civil society.

In the context of the emerging new phase of ecology-development, Chinese cities seem to have increasing demands in ecological conservation in order to remain their role as strong players in inter-city competition for command and information functions. This has been argued by some [87] to represent as an entrepreneurial growth paradigm that some of the Chinese cities have recently experienced. In this paradigm, cities aim at attracting inward investment, increasing local financial revenues and promoting competitiveness [64]. Within that context environmental interests are being institutionalized in the economic domain of prices, markets, and competition at both national and international scale, the quality of life including ecological conservation has been calculated by local decision-makers as an essential factor in promoting a knowledge and innovation-based economy [64]. In comparison, in developed areas, especially on the eastern coast, ecological conservation has been part of the 'high-road' local developmental strategies in response to increasing inter-regional competitions [64]. In these regions, quality of life, which includes ecological conservation, has been regarded as an essential part of promoting a knowledge and innovation-based economy [64]. Some places might invest in environmental policy as part of 'high road' economic development strategies, for instance, an ecological amenity has been proposed in the Hangzhou Concept Plan as one of the three major competitive advantages of the city (including also excellent human resources and potential for high-tech development) [64]. In this sense, local governments have demands in ecological conservation [88].

\subsection{Pressures for Ecological Conservation from the Society}

China has a recent history of environmental NGOs [89]. 
The rise of ENGOs in China has partly been supported by international communication and support from international organizations [90]. It is also partially due to the state concerns of the role of NGOs in China to 'compensate for declining central government influence and shifting local government priorities regarding environmental protection' [91]. At the time of this research during the years 2009-2014, there have been some influential ENGOs in China, they are: 1) Registered NGOs which are Registered as social organizations (e.g. Friends of Nature Green River). 2) Non-profit enterprises which are registered as business enterprises but operate as non-profit organizations (e.g. Global Village of Beijing); 3) Unregistered voluntary groups which are Unregistered organizations that function as NGOs (e.g. Institute of Environment and Development Green Earth Volunteers); 4) Web-based groups (e.g. Green-web, Greener Beijing);5) Student environmental associations(e.g. Sichuan University Environmental Volunteer Association); 6) University research centers/institutes(e.g. Centre for Legal Assistance to Pollution Victims, China University of Political Science and Law, Centre for Biodiversity and Indigenous Knowledge); 7) Government-organized NGOs (GONGOs) which are Social organizations established by government agencies, also known as state-owned NGOs (SONGOs) (e.g. China Environmental Science Association);8)Local-based ENGOs which are Registered as social organizations (e.g. Green Han River); 9) International NGOs in China(e.g. W. Alton Jones Foundation, Ford Foundation, Canadian Civil Society Program etc.). Most of activities of these major ENGOs in China are nation-wide. However, there are also influential local branches around the country. For instance, the Friends of Nature in Beijing now has member groups in Wuhan, Guangzhou, Shenzhen and Shanghai. Restricted by lack of funding and insufficient human capital, constrained by lack of access to data on actual conditions, dependent on government benevolence, and operating in a highly controlled political space, the ability of China's NGOs to influence China's ecological conservation policy development and enforcement is limited [90,91]. The general tendency has been to use non-confrontational methods as one of the major strategies [92]. Therefore, the activities of ENGOs in China are typically restricted to advancing government-approved agendas, including education and awareness building (e.g. public lectures, workshops and conferences, salon discussions, field trips, publication of newsletters and multimedia documents), the advocacy of environmentally friendly lifestyles, and initiating public 'green' campaigns' (such as online discussions, online mailing lists and internet petitions) [90-92]. Recently, some organizations have edged their way into more contentious areas. For instance, in the late 1990s, Friends of Nature and some other ENGOs launched wildlife protection movements, which stopped the forest cutting in the habitat of the golden monkey and the establishment of protected areas for Tibetan antelopes.

In addition to ENGOs in China, there is a trend that autonomous collective actions by civil citizen are playing a crucial role in influencing policy and political agendas [90, 93]. In these actions, citizens usually use the internet, mobile phone messaging, etc. to organize peaceful protest marches against certain projects. Given that demonstrations are forbidden by law in China, these peaceful marches may perhaps show greater potential to have an impact on local decision-making. The example of the PX project, Maglev project and Sinopec project in Guangzhou, all of which were relocated due to collective action organized by citizens, are an indication of this [93]. These pollution-related protests can thus be seen to have imposed great pressure on EPBs, as they may affect the career development prospects of the respective EPB leaders [88] that relates to the target responsibility system.

There are also signs that increasing numbers of experts are becoming involved directly in mobilizing opinion or contesting politics, for instance formal protest or informal lobbying. The evidence of experts participating in, and even initiating and organizing wider environmental lobbying, can be seen in the Xiamen PX project. In addition to this, experts are increasingly gaining political power in decision-making in conservation through other channels. In China, some experts are actively involved in ecological conservation practices, including through establishing their own ENGOs and improving the effectiveness of nature conservation through supporting the economic and social development of localities. A case in point is Peking University Centre for Nature and Society. Founded by Dr. Pan Wenshi, this centre is dedicated to researching and protecting endangered species in China. In order to effectively protect the white-headed languor in Chongzuo GuangXi, Pan raised money to build new schools, health clinics, and bio-gas digesters for local villagers. In the past 15 years, his endeavor to combine research, protection, education and the support of local communities has led to an increase of the languor population from 96 in 1990 to more than 500 [94]. A particularly noteworthy point is that, due to the reputation and authority long being received by experts in Chinese society, there is a degree of freedom in their activities in terms of their geographical mobility and the degree of influence they may exert on local decision-makers. For instance, experts with international or national reputation may have more say in the local decision-making process. This issue is explored further through the case study research.

The media (in particular newspapers) have increasingly intervened in environmental debates and become a relatively democratic platform through which bottom-up voices can be heard and diffused in China especially after 1990. The trend seems to be that mainstream newspapers are playing an important role in opening up debates and informal lobbying and thus influencing the decision-making process of governments. Regional differences are evident in the role and influence of local media. Local newspapers in China's East Coast Regions seem to be more critical than national and provincial newspapers [93]. A case in point is the Nandu Daily in Shenzhen, whose reports are widely regarded as 
stressing unofficial information as reliable and reportable, proclaiming public participation and procedure justice. In recent environmental movements, including articles on topics such as 'Public protest against Algae bloom in Lake Tai, Wuxi', 'Protest against PX project, Xiamen', and 'Debates around the relocation of a $\$ 5 \mathrm{bn}$ refinery and petrochemical plant of Sinopec in Guangzhou'. The Southern Metropolis Daily was the first media to highlight those debates, followed by a serial of media coverage, which finally affected the decision-making process of these projects in localities. However, there are still crucial limitations of the media in the decision-making process. To some extent, the intervention of the media in environment-related issues mainly focuses on some 'gray domains' and the criticism of the media could still be regarded as moderate to some extent [92]. Furthermore, even though the Chinese media has gradually acquired the role of 'mouthpiece of the society', their original role as the 'mouthpiece of the Party' has remained unchanged. This may lead to ever shifting positions of media in confronting various social issues [93].

\subsection{Pressures against Ecological Conservation from Pro-growth Groups}

Since China's accession to the WTO in 2001, international markets have increased dramatically in China. In keeping with the global neo-liberal agenda, environmental interests are being institutionalized in the economic domain of prices, markets, and competition. As concluded by Mol and Carter (2007), this trend is reflected in three ways. First, the prices of ecological resources are increasingly (albeit slowly) being included in cost prices. Second, the central government has increased environmental fees, and made tax reductions for rewarding producers who employ effective techniques to achieve environmental goals. These policies have significantly influenced the (economic) decision-making of some industries and polluters. Third, market demand has started to take the environmental and health dimensions of products and production processes into account.

One of the important consequences of marketization and decentralization has been the pro-growth coalitions involving local state and non-governmental actors [95, 96], who come together to pursue an agenda of urban growth and intensification of land use [66].The common pro-growth interest in China has bound local bureaucracy, enterprises and inward foreign capital into an informal coalition to deal with regional competition and to circumvent central pressure for revenue submission [97]. Most of these growth coalitions are seen as being formed around landed property [97]. Their demands on converting more space resources into local development [97] may shape pressures against ecological conservation in local decision-making.

Local communities, especially local peasants, have been part of these forces opposed to ecological conservation due to their loss of traditional access to natural resources and forced resettlement or displacement as the result of the designation of protected areas. As many have argued, the biggest immediate threat to biodiversity conservation and protected areas in China is illegal agriculture, hunting, and the collection of wood [98]. In China, there are two separate rights of land: the land use rights (which include 'cheng bao quan' - the right of land rental) and land ownership rights under the household responsibility system (HRS). Under the HRS, collectively owned land is averagely contracted to individual households for up to 15 years ${ }^{1}$ [99]. Distribution as well as production is in fact privatized to each household. The peasants are therefore free to organize production and arrange labour forces that are needed inside of the household itself. In consequence, the peasants are accorded various rights, such as the right of benefit and the right of disposition. They are encouraged to enhance productivity since they are free to obtain all of the remaining output or sales proceeds after paying their share of the agricultural tax, selling a quota of the output to the state and meeting the obligation to their village in terms of public accumulation fund and welfare fund, or directly to the public at free market prices [100-102]. However, the designation of protected areas has always restricted traditional access to natural resources and has even resulted in the resettlement or displacement of people. The denial of traditional access to resources may lead to the degradation of ecosystems [20]. For instance, local peasants may abandon traditional sustainable practices or, when local peasants lose their control over and access to land, they may initiate illegal constructions or activities to challenge the legitimacy of the regulatory bodies and force them to change the allocations of the physical spaces.

\section{Conclusions}

This paper aims to explore how the scope of ecological regulation is being shaped by particular political, economic and social contexts, and what implications they may have for the regulation of place and space. The strategic relational approach is used to capture the political structuration of choices about ecological conservation, the 'strategic and spatial selectivity' of the state [103] and especially the asymmetry of power relations. Combining theoretical and empirical investigation, our central argument is that far from being a pure technological application, ecological conservation is a question of social power. In particular, ecological designation should be situated within broader political struggles over the use of land and environmental resources, and the values attached to nature and ecology.

Different ministries or administrations at various levels (both central state and local governments) are working together to jointly manage conservation reserves according to their different conservation status (national, provincial, municipal, etc.), classified by the significance of their ecological, economic and social values. The central state provides guidelines for the designation and management of

1 It was ruled in 1978 that the contract would last for up to 15 years, but this limitation had been changed into 30 years, when most of the contracts were due in 1993. 
protected areas through three strategies: the national planning framework, the formulation of the principles and criteria in the establishment of protected areas, and a three-step statutory procedure in the designation of protected areas. National Academy of Science and University academics, experts and relevant governmental officers are also involved in these procedures as key actors providing an additional quality control mechanism, involving the provision of essential endorsements in the application and the assessment of an application. Empowered by both international values and national ideology, together with concerns about ecological degradation, a strong coalition of interests is emerging that argues for the conservation of ecological areas. These social groups and actors include experts, NGOs and GOs, the media, and other social actors. These groups and actors usually back competing representations about locally fixed natural resources and space, and their competing claims over the use of conservation reserves shape a set of forces and pressures for sub-national decision-makers. Ultimately, the actual key design features of the designation of ecologically sensitive areas - such as the territories, scale, and boundaries of a conservation reserve - could be argued to reflect governments' desire to balance environmental and ecological goals with other forces, pressures, and demands within the wider society with strategic selectivity of the state.

Predicting the future is yet still a risky venture especially in China where ecological conservation has been affected by massive nationwide restructuring of its urban system and rapid changes to the political system that underpinned this restructuring [104]. However, it might be possible to argue that with the increasingly in-depth cooperation with international organization or agencies, more international norms and rules will be introduced in China. This also means the various ways in which China may participate into the new round of international competition and co-operation. Within this context, the politics of the state in ecological regulation would be the core for further research. This involves analysis of possible transitions in power relations that are involved in the process of ecological governance, when predictable social and political transition may come along with the economic globalization, and more interest groups may be involved in the decision-making process of ecological governance. One dimension of future research is to look into the power struggle across scales within the state. Another dimension is enquiry into the ways in which the power of the civil society may have influenced ecological policy. It is also necessary to investigate how regional competition may exert impacts on the way in which state powers are reorganized. Future ecological regulation/governance policy should take into account a range of social and economic impacts of ecological policy. It is possible that ecological conservation will benefit and trade-off economic, social and physical infrastructures investment of some already economically successful places, which may be achieved through adding on existing inter-place competition [11, 25]. Whereas for those economically marginalized areas where growth is largely dependent on a resourced-based economy, one of the possible outcomes of the designation of ecological reserves may be the further intensified spatial unevenness of environment-development conditions [2, 11]. Above all, further research into and informing the practice of and practice on the social justice of ecological regulation/governance is required.

\section{Acknowledgements}

This paper is based on the author's $\mathrm{PhD}$ project, which was supported by University of Sheffield Scholarship. Further development of the paper is supported by China National Social Science Foundation under Grant 14CGL052; and Jinan University China under Grant 12615802 and Higher Level University Construction Fund. The author wishes to thank Dr. Aidan H While for helpful suggestions and advice on matters relating to this paper. The reviewers' comments were exceptionally useful in prompting revisions. The usual disclaimers apply.

\section{REFERENCES}

[1] Adams WM. Rationalization and Conservation: Ecology and the Management of Nature in the United Kingdom. Transactions of the Institute of British Geographers. 1997; 22(3):277-91.

[2] Zimmerer KS. The Reworking of Conservation Geographies: Non equilibrium Landscapes and Nature Society Hybrids. Annals of the Association of American Geographers. 2000; 90(2):356-69.

[3] Adams WM, Hutton J. People, parks and poverty: Political ecology and biodiversity conservation. Conservation and society. 2007;5(2):147.

[4] Jepson P, Whittaker RJ. Histories of protected areas: inter-nationalization of conservationist values and their adoption in the Netherlands Indies (Indonesia). Environment and History. 2002; 8(2):129-72.

[5] Kalamandeen M, Gillson L. Demything Wilderness? implications for protected area designation and management. BIODIVERS CONSERV. 2007; 16(1):165-82.

[6] Cox CB, Moore PD. Biogeography: an ecological and evolutionary approach: Wiley 2010.

[7] MacArthur RH, Wilson EO. The theory of island biogeography: Princeton Univ Pr 2001.

[8] McIntosh RP. The background of ecology: concept and theory: Cambridge Univ Pr 1986.

[9] Margules CR, Pressey RL. Systematic conservation planning. NATURE. 2000; 405(6783):243-53.

[10] Yaffee SL. Three faces of ecosystem management. CONSERV BIOL. 1999; 13(4):713-25. 
[11] Gibbs D, While A, Jonas A. Governing nature conservation: the European Union Habitats Directive and conflict around estuary management. Environment and Planning A. 2007;39(2):339-58.

[12] Scoones I. NEW ECOLOGY AND THE SOCIAL SCIENCES: What Prospects for a Fruitful Engagement? Annual Review of Anthropology. 1999; 28(1):479-507.

[13] Swyngedouw E. Social power and the urbanization of water: flows of power: Oxford University Press, USA 2004.

[14] Jessop B. Interpretive sociology and the dialectic of structure and agency. Theory, Culture \& Society. 1996; 13(1):119-28.

[15] Tsunekawa A, Liu G, Yamanaka N, Du S. Restoration and Development of the Degraded Loess Plateau, China: Springer 2014.

[16] Delang CO, Yuan Z. China's grain for green program: a review of the largest ecological restoration and rural development program in the world: Springer 2014

[17] Xie J. Addressing China's water scarcity: recommendations for selected water resource management issues: World Bank Publications 2009.

[18] Carreiro MM, Song Y, Wu J. Ecology, Planning, and Management of Urban Forests: International Perspective: Springer Science \& Business Media 2007.

[19] Yin R. An integrated assessment of China's ecological restoration programs: Springer.

[20] Xu J, Melick DR. Rethinking the effectiveness of public protected areas in southwestern China. CONSERV BIOL. 2007; 21(2):318-28.

[21] Jim CY, Xu SSW. Recent protected area designation in China: An evaluation of administrative and statutory procedures. Geographical Journal. 2004; 170(1):39-50.

[22] Zhou DQ, Edward Grumbine R. National parks in China: Experiments with protecting nature and human livelihoods in Yunnan province, Peoples' Republic of China (PRC). BIOL CONSERV. 2011

[23] Jessop B, Brenner N, Jones M. Theorizing sociospatial relations. Environment and Planning D: Society and Space. 2008 2008-01-01; 26(3):389-401.

[24] Cox KR. Spaces of dependence, spaces of engagement and the politics of scale, or: looking for local politics. Political geography. 1998; 17(1):1-23.

[25] While A, Jonas AEG, Gibbs D. From sustainable development to carbon control: eco state restructuring and the politics of urban and regional development. Transactions of the Institute of British Geographers. 2010; 35(1):76-93.

[26] Blaikie P, Jeanrenaud S. Biodiversity and human welfare. Social change and conservation. Earthscan, London. 1997:46-70.

[27] Rands M, Adams WM, Bennun L, Butchart S, Clements A, Coomes D, et al. Biodiversity Conservation: Challenges Beyond 2010. SCIENCE. 2010; 329(5997):1298-303.

[28] Assessment ME. Ecosystems and human well-being: Island Press 2005.

[29] De Groot RS. Environmental functions and the economic value of natural ecosystems. In: A. Jansson et al., ed. Investing in natural capital: the ecological economics approach to sustainability: Island Press Int. Soc. Ecological Economics 1994:151-68

[30] Goulder LH, Kennedy D. Valuing ecosystem services: philosophical bases and empirical methods: Island Press, Washington, DC 1997.

[31] Meletis Z A, Campbell LM. Call It Consumption! Re Conceptualizing Ecotourism as Consumption and Consumptive. Geography Compass. 2007; 1(4): 850-70.

[32] Wilson C, Tisdell C. Sea turtles as a non-consumptive tourism resource especially in Australia. Tourism Management. 2001; 22(3):279-88.

[33] Alcamo J, Bennett EM. Ecosystems and human well-being: a framework for assessment: Island Pr 2003.

[34] Ronnback P. The ecological basis for economic value of seafood production supported by mangrove ecosystems. ECOL ECON. 1999; 29(2):235-52.

[35] Greenley DA, Walsh RG, Young RA. Option value: empirical evidence from a case study of recreation and water quality. The quarterly journal of economics. 1981; 96(4):657.

[36] Smith VK. Option value: A conceptual overview. Southern economic journal. 1983:654-68.

[37] Whittaker RJ, Fernández JM. Island biogeography: ecology, evolution, and conservation: Oxford University Press, USA 2007.

[38] Mol APJ. Ecological modernization: industrial transformations and environmental reform. The international handbook of environmental sociology. 1997:138-49.

[39] Hajer MA. The politics of environmental discourse: ecological modernization and the policy process: Oxford University Press, USA 1995.

[40] Mol AP, Spaargaren G. Ecological modernisation theory in debate: a review. Environmental politics. 2000; 9(1):17-49.

[41] Spaargaren G, Mol APJ. Sociology, environment, and modernity: Ecological modernization as a theory of social change. Society and Natural Resources. 1992; 5(4):323-44.

[42] Harvey D. Justice, nature and the geography of difference: Wiley-Blackwell 1996.

[43] Jessop B. The capitalist state: Marxist theories and methods: New York University Press New York 1982.

[44] Jessop B. State theory: putting states in their place: Pennsylvania State University Press 1990.

[45] Hay C. Structure and agency. In: D. Marsh \& G. Stoker, ed. Theory and Methods of Political Science. London: Macmillan 1995:189-206.

[46] Jessop B. Critical realism and the strategic-relational approach. New Formations. 2005; 56: 40.

[47] Jessop B. Institutional re (turns) and the strategic-relational approach. Governing local and regional economic development: Institutions, politics and economic development. 2004:23-49.

[48] Swyngedouw E, Heynen NC. Urban political ecology, justice 
and the politics of scale. Antipode. 2003; 35(5):898-918.

[49] Jessop B. The future of the capitalist state: Polity Pr 2002.

[50] Hancock B, Ockleford E, Windridge K. An introduction to qualitative research: Trent focus group Nottingham 1998.

[51] Flick U, Von Kardorff E, Steinke I. A companion to qualitative research: Sage Publications Ltd 2004.

[52] Yin RK. Case study research: Design and methods: Sage Publications, Inc 2009.

[53] Stewart DW, Kamins MA. Secondary research: Information sources and methods: Sage Publications, Inc 1993.

[54] Harris RB. Wildlife conservation in China: preserving the habitat of China's Wild West: ME Sharpe Inc 2008.

[55] Silverman D. Doing qualitative research: A practical handbook: Sage Publications Ltd 2005.

[56] Patton MQ. Qualitative evaluation and research methods.: Sage Publications, Inc 1990.

[57] Corbin JM, Strauss AL. Basics of qualitative research: Techniques and procedures for developing grounded theory: Sage Publications, Inc 2008.

[58] Pope C, Ziebland S, Mays N. Analysing qualitative data. Bmj. 2000; 320(7227):114.

[59] Qu G, Gan H. Environmental management in China: United Nations Environment Programme 1991.

[60] Zhu J. Nature conservation in China. J APPL ECOL. 1989; 26(3):825-33.

[61] Harkness J. Recent trends in forestry and conservation of biodiversity in China. The China Quarterly. 1998; 156(-1):911-34.

[62] Mackinnon JR. A biodiversity review of China: World Wide Fund for Nature (WWF) International, WWF China Programme 1996.

[63] Liu J, Ouyang Z, Pimm SL, Raven PH, Wang X, Miao H, et al. Protecting China's biodiversity. SCIENCE. 2003; 300(5623):1240.

[64] Wu F, Zhang J. Planning the Competitive City-Region. Urban Affairs Review. 2007; 42(5):714.

[65] Malecki E. Jockeying for position: what it means and why it matters to regional development policy when places compete. Regional Studies. 2004; 38(9):1101-20.

[66] $\mathrm{Xu} \mathrm{J,} \mathrm{Yeh} \mathrm{A.} \mathrm{Decoding} \mathrm{urban} \mathrm{land} \mathrm{governance:} \mathrm{state}$ reconstruction in contemporary Chinese cities. Urban Studies. 2009; 46(3):559-81.

[67] State Council Committee For Protection C. Planning framework for nature reserve development in China: 1996-2010. 1997.

[68] PRC State Council. PRC Land Administration Law Implementing Regulations. 2009-9-20 ed 1998.

[69] Ministry Of Environmental Protection C. Organizational and Institutional System of the National Nature Reserve Assessment Committee. 2011-6-2 ed 1999.

[70] NEPA, State Planning Commission C. Circular on printing and distribution of the 'Planning Framework for Circular on printing and distribution of the 'Planning Framework for Nature Reserve Development in China: 1996-2010. 1997.

[71] The State Council Of China. The National Eleventh Five-year Plan for Environmental Protection. 2007.

[72] SEPA. Planning Outline of the National Key Ecological Function Areas. 2007.

[73] Gibbs D, Jonas A, While A. Changing governance structures and the environment: economy-environment relations at the local and regional scales. Journal of Environmental Policy \& Planning. 2002; 4(2):123-38.

[74] Castree N. Neoliberalising nature: the logics of deregulation and reregulation. Environment and Planning A. 2008; 40(1):131-52.

[75] Castree N. Neoliberalising nature: processes, effects, and evaluations. Environment and planning A. 2008; 40(1):153-73.

[76] Cox KR, Jonas AEG. Urban development, collective consumption and the politics of metropolitan fragmentation. Political Geography. 1993; 12(1):8-37.

[77] Robertson MM. The neoliberalization of ecosystem services: wetland mitigation banking and problems in environmental governance. Geoforum. 2004; 35(3):361-73.

[78] Robertson MM. The nature that capital can see: science, state, and market in the commodification of ecosystem services. Environment and Planning D: Society and Space. 2006 2006-01-01; 24(3):367-87.

[79] Castree N. Making First World political ecology. 2007 2007-01-01; 39(8):2030-6.

[80] Falkner R. International sources of environmental policy change in China: the case of genetically modified food. PACIFIC REVIEW-OXFORD-. 2006; 19(4):473.

[81] Qu G, Gan H. Environmental management in China: United Nations Environment Programme 1991.

[82] Cooper DE. Kyoto Protocol and China: Global Warming's Sleeping Giant, The. Geo. Int'l Envtl. L. Rev. 1998; 11: 401.

[83] Zhang K, Wen Z. Review and challenges of policies of environmental protection and sustainable development in China. J ENVIRON MANAGE. 2008;88(4):1249-61.

[84] Xun Z, Milly W. National geoparks initiated in China: putting geoscience in the service of society. Episodes-Newsmagazine of the International Union of Geological Sciences. 2002; 25(1):33-7.

[85] Fan CC. China's Eleventh Five-Year Plan (2006-2010): From" Getting Rich First" to" Common Prosperity". Eurasian Geography and Economics. 2006; 47(6):708-23.

[86] Naughton B. The New Common Economic Program: China's Eleventh Five Year Plan and What It Means. China Leadership Monitor. 2005; 16.

[87] Oksenberg M, Tong J. The evolution of central-provincial fiscal relations in China, 1971-1984: the formal system. China Quarterly. 1991; 125: 1-32.

[88] Shi H, Zhang L. China's environmental governance of rapid industrialisation. Environmental politics. 2006; 15 (02): 
271-92.

[89] Mol APJ, Carter NT. China's environmental governance in transition. Environmental Politics. 2006; 15(2):149-70.

[90] Fu T. China's environmental NGO. Research Center for Environment and Development, Chinese Academy of Social/China Environment and Development Review. 2004; 456(2):14-5.

[91] Schwartz J. Environmental NGOs in China: roles and limits. Pacific Affairs. 2004; 77(1):28-49.

[92] Yang G. Environmental NGOs and institutional dynamics in China. The China Quarterly. 2005; 181(-1):46-66.

[93] Zeng F. The role of the media in environmental movement in contemporary China. Modern Advertising. 2009(08X):36-41.

[94] Interview, Experts no.1. 2008.

[95] Oi JC. The role of the local state in China's transitional economy. The China Quarterly. 1995:1132-49.

[96] Lin GC, Lin GCS. Red capitalism in South China: growth and development of the Pearl River Delta: Univ of British Columbia Pr 1997.

[97] Zhu J. Local growth coalition: the context and implications of
China's gradualist urban land reforms. International Journal of Urban and Regional Research. 1999; 23(3):534-48.

[98] Xu J, Wilkes A. Biodiversity impact analysis in northwest Yunnan, southwest China. BIODIVERS CONSERV. 2004; 13(5):959-83.

[99] Lin JY. Rural reforms and agricultural growth in China. The American Economic Review. 1992; 82(1):34-51.

[100] Ash RF. The evolution of agricultural policy. The China Quarterly. 1988:529-55.

[101]Dong XY. Two-tier land tenure system and sustained economic growth in post-1978 rural China. World Development. 1996; 24 (5):915-28.

[102] Liu J. The Relationship among the Nation, the Collectivity and the Farmer during the Change of Collective Property Rights: Central China Normal University; 2003.

[103] Jessop B. Liberalism, neoliberalism, and urban governance: a state-theoretical perspective. Spaces of Neoliberalism: Urban Restructuring in North America and Western Europe. 2002:105-25.

[104]Zacharias J, Tang Y. Restructuring and repositioning Shenzhen, China's new mega city. Progress in Planning. 2010; 73 (4):209-49. 